\title{
A New Variant of Dual Left Anterior Descending Artery Anomaly Type XI
}

"Rashid S. Al-Umairi, Faiza A. Al-Kindi, Saqar A. Al-Tai

$$
\text { نوع جديد من ازدواجية الشريان التاجي النازل الامامي }
$$

راشد العميري، فايزة الكندية، صقر الطائي

ABSTRACT: A dual left anterior descending (LAD) artery is a rare congenital anomaly which is classified into different types based on the origin, course and termination of the short and long LAD arteries. To date, 10 variants of dual LAD artery anomalies have been described. We report a 44-year-old woman who was referred to the Department of Radiology, Royal Hospital, Muscat, Oman, in 2017. Coronary computed tomography angiography revealed a dual LAD artery anomaly in which the short and long LAD arteries shared a common ostium with the right coronary artery from the right coronary sinus. To the best of the authors' knowledge, this type of variant has not been previously reported in the literature.

Keywords: Coronary Angiography; Congenital Abnormality; Coronary Vessel Anomalies; Case Report; Oman.

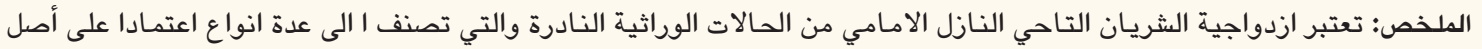

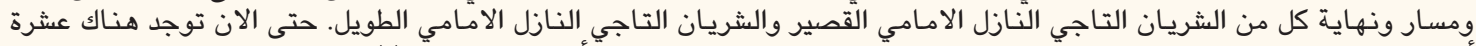

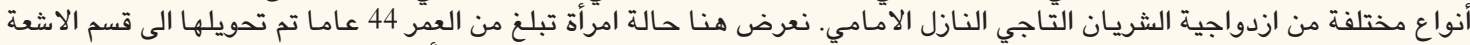

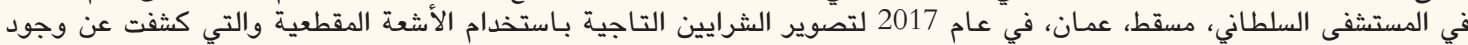

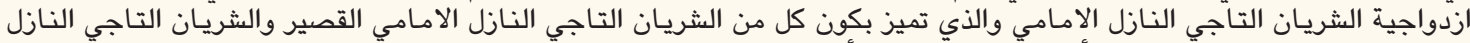

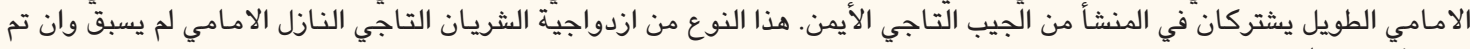

تصنيفة من قبل.

$$
\text { الكلمات المفتاحية؛ تصوير الاوعية التاجية؛ تشوهات خلقية؛ تشوهـات الشريان التاجية؛ تقرير عن حالة؛ عمان. }
$$

A DUAL LEFT ANTERIOR DESCENDING (LAD) artery is a rare coronary anomaly with an estimated incidence of $0.03-0.2 \%$ among patients undergoing routine coronary catheterisation. ${ }^{1}$ It is defined as the presence of both short and long LAD arteries. ${ }^{2}$ Awareness of the different types of dual LAD artery anomalies is critical when planning percutaneous and surgical reperfusion strategies. ${ }^{2-4}$ This report describes a unique case which, to the best of the authors' knowledge, does not fall into any of the 10 categories of dual LAD artery anomalies currently reported in the literature. ${ }^{5,6}$

\section{Case Report}

A 44-year-old woman was referred to the Department of Radiology, Royal Hospital, Muscat, Oman, in 2017 for coronary computed tomography angiography (CCTA). She had a history of chest pain, shortness of breath upon exertion and palpitations. However, a physical examination, electrocardiogram and cardiac enzyme testing were normal. Therefore, 384-slice CCTA was performed at $2 \times 192 \mathrm{~kW}$. This revealed a dual LAD artery anomaly in which the short and long LAD arteries shared a common ostium with the right coronary artery from the right coronary sinus [Figure 1A]. The short LAD artery followed a course caudal to the pulmonary artery and through the interventricular septum to the left, before emerging within the proximal anterior interventricular groove where it terminated as the first diagonal branch. The long LAD artery coursed anterior to the pulmonary artery to the left and then entered the distal interventricular groove [Figure 1B]. The left circumflex artery originated from the right coronary sinus then followed a retroaortic course before reaching the left atrioventricular groove [Figures $1 \mathrm{C}$ and $\mathrm{D}$ ].

There was no evidence of coronary artery atherosclerotic disease and no other congenital anomalies were detected. As there were no signs of any stenosis of significant haemodynamic severity, the decision was made to keep the patient under regular observation and follow-up. 

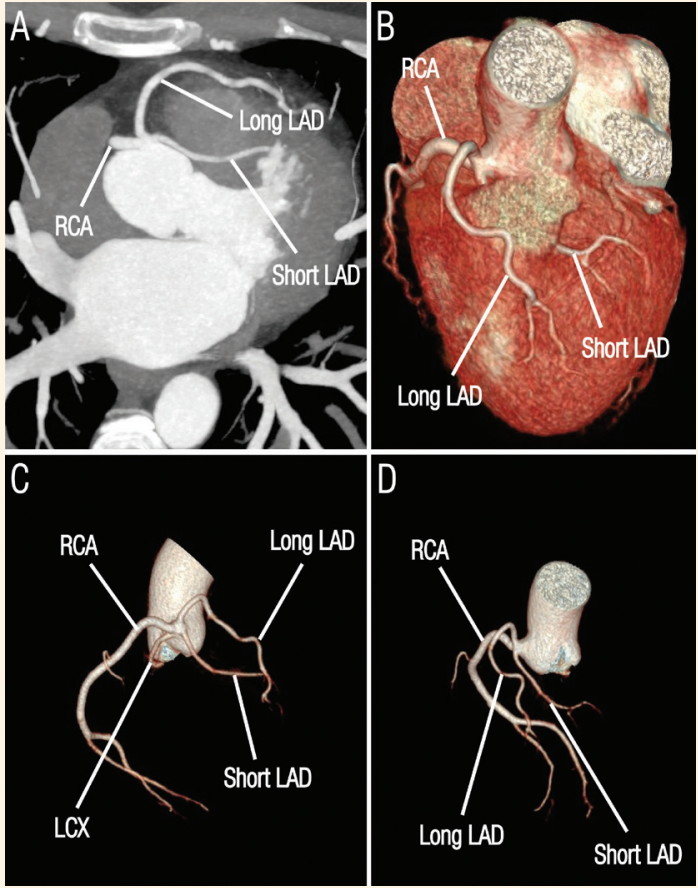

Figure 1: Coronary computed tomography angiography (CCTA) sequence of a 44-year-old woman with a dual left anterior descending (LAD) artery anomaly. A: Axial maximum-intensity projected CCTA image showing the anomalous origin of the long and short LAD arteries from the right coronary sinus with a prepulmonic course for the long LAD artery and transeptal course for the short LAD artery. B: Three-dimensional volume-rendered CCTA image showing the course of the long LAD artery anterior to the right ventricular outflow track and entering the distal anterior interventricular groove. C \& D: Threedimensional volume-rendered CCTA images showing the common origin of the long LAD artery, short LAD artery, right coronary artery and left circumflex artery from the right coronary sinus.

$L A D=$ left anterior descending artery; $R C A=$ right coronary artery; $L C X=$ left circumflex artery.

\section{Discussion}

Normally, the LAD artery originates from the left main coronary artery and then courses within the anterior interventricular groove towards the apex where it gives rise to diagonal and septal branches. In contrast, a dual LAD artery is a rare congenital anomaly characterised by the presence of short and long LAD arteries. ${ }^{1,2}$ It is traditionally classified into four different types based on the origin, course and termination of the short and long LAD arteries. ${ }^{25,7}$ However, CCTA has since enabled the recognition of other variants. To date, 10 dual LAD artery variants have been described [Table 1]. 5,6 The short LAD artery typically originates from the main stem of the LAD artery and terminates in the proximal interventricular groove. The long LAD artery takes a more variable course around the short segment, returning to the interventricular groove distally., ${ }^{2,6,8,9}$

In previously described cases of dual LAD artery anomalies, the short LAD artery originates from either
Table 1: Types of dual left anterior descending artery variants ${ }^{5,6}$

\begin{tabular}{|c|c|c|c|c|}
\hline \multirow[t]{2}{*}{ Type } & \multicolumn{2}{|c|}{ Short LAD artery } & \multicolumn{2}{|c|}{ Long LAD artery } \\
\hline & Origin & Course & Origin & Course \\
\hline I & LMCA & $\begin{array}{l}\text { Proximal } \\
\text { AIVG }\end{array}$ & $\begin{array}{l}\text { Proximal } \\
\text { LAD } \\
\text { artery }\end{array}$ & $\begin{array}{l}\text { Epicardial course on } \\
\text { the LV side of the } \\
\text { proximal AIVG and } \\
\text { then re-enters the } \\
\text { distal AIVG }\end{array}$ \\
\hline II & LMCA & $\begin{array}{l}\text { Proximal } \\
\text { AIVG }\end{array}$ & $\begin{array}{l}\text { Proximal } \\
\text { LAD } \\
\text { artery }\end{array}$ & $\begin{array}{l}\text { Epicardial course on } \\
\text { the RV side of the } \\
\text { proximal AIVG and } \\
\text { then re-enters the } \\
\text { distal AIVG }\end{array}$ \\
\hline III & LMCA & $\begin{array}{l}\text { Proximal } \\
\text { AIVG }\end{array}$ & $\begin{array}{l}\text { Proximal } \\
\text { LAD } \\
\text { artery }\end{array}$ & $\begin{array}{l}\text { Intramyocardial } \\
\text { course in the proximal } \\
\text { septum followed by an } \\
\text { epicardial course in } \\
\text { the distal AIVG }\end{array}$ \\
\hline IV & LMCA & $\begin{array}{l}\text { Proximal } \\
\text { AIVG }\end{array}$ & RCA & $\begin{array}{l}\text { Epicardial course } \\
\text { anterior to the RVOT } \\
\text { and then enters the } \\
\text { distal AIVG }\end{array}$ \\
\hline V & LCS & $\begin{array}{l}\text { Proximal } \\
\text { AIVG }\end{array}$ & RCS & $\begin{array}{l}\text { Intramyocardial } \\
\text { course within the } \\
\text { septal crest and then } \\
\text { emerges in the distal } \\
\text { AIVG }\end{array}$ \\
\hline VI & LMCA & $\begin{array}{l}\text { Proximal } \\
\text { AIVG }\end{array}$ & RCA & $\begin{array}{l}\text { Course between the } \\
\text { RVOT and aortic root } \\
\text { and then enters the } \\
\text { mid or distal AIVG }\end{array}$ \\
\hline VII & $\begin{array}{l}\text { LAD } \\
\text { artery }\end{array}$ & $\begin{array}{l}\text { Proximal } \\
\text { AIVG }\end{array}$ & $\begin{array}{l}\text { LAD } \\
\text { artery }\end{array}$ & $\begin{array}{l}\text { Epicardial course on } \\
\text { the LV side of the } \\
\text { proximal AIVG and } \\
\text { then re-enters the } \\
\text { distal AIVG* }\end{array}$ \\
\hline $\begin{array}{l}\text { New } \\
\text { variant } \\
\text { of type } \\
\text { VII }\end{array}$ & LMCA & $\begin{array}{l}\text { Proximal } \\
\text { AIVG }\end{array}$ & RCS & $\begin{array}{l}\text { Course on the LV side } \\
\text { of the proximal AIVG } \\
\text { and the re-enters the } \\
\text { distal AIVG" }\end{array}$ \\
\hline VIII & LMCA & $\begin{array}{l}\text { Proximal } \\
\text { AIVG }\end{array}$ & Mid-RCA & $\begin{array}{c}\text { Epicardial course on } \\
\text { the inferior wall of } \\
\text { the RV and then turns } \\
\text { around the apex and } \\
\text { reaches the distal } \\
\text { AIVG }^{+}\end{array}$ \\
\hline IX & LAD & Mid AIVG & $\begin{array}{l}\text { LAD } \\
\text { artery }\end{array}$ & $\begin{array}{l}\text { Epicardial course } \\
\text { on the LV side of } \\
\text { the proximal AIVG } \\
\text { and then re-enters } \\
\text { the distal AIVG and } \\
\text { terminates before } \\
\text { reaching the apex }\end{array}$ \\
\hline $\mathrm{X}$ & LMCA & $\begin{array}{l}\text { Proximal } \\
\text { AIVG }\end{array}$ & RCS & $\begin{array}{l}\text { Epicardial course } \\
\text { anterior to the RVOT } \\
\text { and then enters the } \\
\text { distal AIVG }\end{array}$ \\
\hline $\begin{array}{l}\text { Current } \\
\text { case } \\
\text { (XI) }\end{array}$ & RCS & $\begin{array}{l}\text { Intramyocardial } \\
\text { course within } \\
\text { the proximal } \\
\text { septum and } \\
\text { then emerges } \\
\text { in the proximal } \\
\text { AIVG }\end{array}$ & RCS & $\begin{array}{l}\text { Epicardial course } \\
\text { anterior to the RVOT } \\
\text { and then enters the } \\
\text { distal AIVG }\end{array}$ \\
\hline
\end{tabular}

$L A D=$ left anterior descending; $L M C A=$ left main coronary artery; $A I V G=$ anterior interventricular groove; $L V=$ left ventricular; $R V=$ right ventricular; $R C A=$ right coronary artery; $R V O T=$ right ventricle out-flow tract; $L C S=$ left coronary sinus; $R C S=$ right coronary sinus. "The LMCA originates from the RCS and has an interarterial malignant course. ${ }^{+}$The LMCA originates from the RCS and has a retroaortic course. ${ }^{7}$ The posterior descending coronary artery extends distal to the AIVG. 
the main stem of the LAD artery or the left main coronary artery. ${ }^{1-10}$ However, the current case was unique in that the short LAD originated from the right coronary sinus and then coursed within the proximal septum before emerging in the proximal interventricular groove. The long LAD artery originated from the right coronary sinus and then coursed anterior to the main pulmonary artery before entering the distal interventricular groove. To the best of the authors' knowledge, this type of LAD artery anomaly has not been previously reported in the literature and may be considered a new variant (type XI).

During conventional coronary angiography, the entire coronary vasculature might not be visible, particularly in cases wherein the coronary arteries have anomalous origins. Awareness of potential dual LAD artery variants is therefore crucial when interpreting cardiac imaging as well as in the planning of percutaneous and surgical reperfusion strategies. For example, among patients with variants in which the long LAD artery originates from the right coronary sinus, only the short LAD artery can be visualised via angiography which means it may be mistaken for a mid-LAD artery occlusion. ${ }^{6}$ Furthermore, among patients requiring a coronary bypass graft, a lack of awareness may result in a bypass to only one artery, thus leading to deficient revascularisation if both the short and long LAD arteries are stenosed. In addition, awareness of the various dual LAD artery variants can prevent vascular injuries during a median sternotomy in cases wherein the long LAD artery courses anterior to the pulmonary artery behind the sternum. ${ }^{6,10}$

\section{Conclusion}

A dual LAD artery is a rare congenital anomaly and awareness of the various types of dual LAD artery variants is critical. The current case report describes a new variant of dual LAD artery anomaly, provisionally designated type XI, in which the short LAD artery orig- inated from the right coronary sinus and then coursed within the proximal septum before emerging in the proximal interventricular groove, while the long LAD coursed anterior to the pulmonary artery to the left and then entered the distal interventricular groove.

\section{References}

1. Peixoto Oliveira MD, de Melo PH, Esteves Filho A, Kajita LJ, Ribeiro EE, Lemos PA. Type 4 dual left anterior descending artery: A very rare coronary anomaly circulation. Case Rep Cardiol 2015; 2015:580543. doi: 10.1155/2015/580543.

2. Spindola-Franco H, Grose R, Solomon N. Dual left anterior descending coronary artery: Angiographic description of important variants and surgical implications. Am Heart J 1983; 105:445-55. doi: 10.1016/0002-8703(83)90363-0.

3. Moulton KM, Kraushaar G, Fladeland DA. An unusual case of dual left anterior descending artery with coronary computed tomographic angiographic correlation. Case Rep Radiol 2013; 2013:348624 doi: 10.1155/2013/348624.

4. Manchanda A, Qureshi A, Brofferio A, Go D, Shirani J. Novel variant of dual left anterior descending coronary artery. J Cardiovasc Comput Tomogr 2010; 4:139-41. doi: 10.1016/j.jcct.2009. 12.007 .

5. Bozlar U, Uğurel MŞ, Sarı S, Akgün V, Örs F, Taşar M. Prevalence of dual left anterior descending artery variations in CT angiography. Diagn Interv Radiol 2015; 21:34-41. doi: 10.5152/ dir.2014.14275

6. Celik T, Bozlar U, Ozturk C, Balta S, Verim S, Demir M, et al. A new anomaly of the left anterior descending artery: Type $\mathrm{X}$ dual LAD. Indian Heart J 2015; 67:S14-17. doi: 10.1016/j.ihj.20 15.09.004.

7. Baydar O, Oktay V, Coskun U, Yildiz A, Gurmen T. A rare case of type IV dual left anterior descending coronary artery. J Clin Diagn Res 2016; 10:OD15-16. doi: 10.7860/JCDR/2016/17489. 7424.

8. Vohra A, Narula H. Dual left anterior descending artery with anomalous origin of long LAD from pulmonary artery: Rare coronary anomaly detected on computed tomography coronary angiography. Indian J Radiol Imaging 2016; 26:201-5. doi: 10.4103/0971-3026.184423.

9. Nasrin S, Cader FA, Haq MM, Shafi MJ. Type IV dual left anterior descending coronary artery: A case report. BMC Res Notes 2017; 10:659. doi: 10.1186/s13104-017-2984-z.

10. Agarwal PP, Kazerooni EA. Dual left anterior descending coronary artery: CT findings. AJR Am J Roentgenol 2008; 191:1698-701. doi: 10.2214/AJR.08.1193. 